\title{
Five tests for a theory of the crime drop
}

\author{
Graham Farrell
}

\begin{abstract}
Many studies have sought to explain the major crime declines experienced in most advanced countries. Key hypotheses relate to: lead poisoning; abortion legalization; drug markets; demographics; policing numbers and strategies; imprisonment; strong economies; the death penalty; gun control; gun concealment; immigration; consumer confidence; the civilizing process, and; improved security. This paper outlines five tests that a hypothesis should pass to be considered further. It finds that fourteen of the fifteen hypotheses fail two or more tests. The security hypothesis appears to pass the tests, and thereby pave the way for further research.
\end{abstract}

Keywords: Crime drop; Crime decline; Crime fall

\section{Background}

Most advanced countries have experienced a major decline in street crime during the last two decades, but with some variation in the extent, timing, and crimes involved. This 'crime drop' was heralded in the United States where total violent crime fell over seventy percent between 1993 and 2011 (Truman and Planty 2012). Some property crimes in the US, particularly burglary and theft, have been falling since the early 1970s according to the National Crime Victimization Survey. Also in the mid-1990s, the UK began to experience dramatic declines across a wide range of property, personal and violent crimes, many falling by half or more (Office of National Statistics 2013). The sharp drops in Canada's homicide and other crime has generally been remarkably similar to that in the US (Ouimet 2002a), while New Zealand experienced rather similar declines in property crime (burglary, motor vehicle theft, and other theft) but not all personal crimes (Mayhew 2012). In this context, the crime drop in Australia seems delayed, beginning around 2001 where after motor vehicle theft led steep falls in burglary, theft and robbery but not some personal crimes (Mayhew 2012). There is considerable evidence, from the International Crime Victims Survey in particular, that most European countries have experienced significant crime drops (van Dijk et al. 2008, van Dijk 2008, van Dijk et al. 2012), tempered by some analysis of the variation (Aebi and Lande 2012), and the suggestion that Switzerland has not (Killias and Lanfranconi 2012). While recognising variation between and within countries, Tseloni et al. (2010) suggest the crime drop is more widespread than advanced countries and could perhaps be labeled as global. Knepper (2012) reviews the evidence from both sides and concludes there is a significant and widespread international crime drop with some variation in its nature.

There have been various efforts to try to explain the crime drop over the last two decades. Fifteen key hypotheses from the academic literature are summarized in Table 1. This includes twelve identified in the reviews of Levitt (2004) and Blumstein and Rosenfeld (2008), and readers are referred to those studies for additional details. Three hypotheses are included that have gained ground since those reviews, and they are referenced further herein. Since crime drop research has expanded in recent years, it is possible that this is not an exhaustive list of hypotheses. However, it should be possible to apply the present study's approach to other hypotheses.

This study sets out five tests that, it is proposed, a crime drop hypothesis must pass to be considered worthy of further scrutiny. The tests are proposed as necessary but not sufficient criteria to identify a viable theory of the crime drop. 
Table 1 Fifteen hypotheses

\begin{tabular}{|c|c|}
\hline Name & Mechanism \\
\hline Strong economy & Wealthy offenders commit less crime \\
\hline Concealed weapons laws & More defensive guns, less crime \\
\hline Capital punishment & More death penalty deterred crime \\
\hline Gun control laws & Less guns, less crime \\
\hline Rising prison population & $\begin{array}{l}\text { Incapacitation and deterrence } \\
\text { reduce crime }\end{array}$ \\
\hline Policing strategies & $\begin{array}{l}\text { Policing focused on crime problems } \\
\text { (Compstat, POP) }\end{array}$ \\
\hline More police & $\begin{array}{l}\text { More police detected and } \\
\text { deterred crime }\end{array}$ \\
\hline Legalization of abortion & $\begin{array}{l}\text { More abortion since } 1973, \\
\text { less offenders by } 1990 \text { s }\end{array}$ \\
\hline Immigration & $\begin{array}{l}\text { Immigrants commit less crime, } \\
\text { so crime fell as immigration rose }\end{array}$ \\
\hline Consumer confidence & $\begin{array}{l}\text { Wealthy buy less from stolen } \\
\text { goods markets }\end{array}$ \\
\hline Waning crack market & $\begin{array}{l}2^{\text {nd }} \text { generation youth deterred } \\
\text { by violence and prison for elders }\end{array}$ \\
\hline Childhood lead & $\begin{array}{l}\text { Lead poisoning of children } \\
\text { made them adolescent criminals }\end{array}$ \\
\hline Changing demographics & $\begin{array}{l}\text { Aging population means relatively } \\
\text { less young offenders }\end{array}$ \\
\hline Civilizing process & $\begin{array}{l}\text { Social institutions more legitimate } \\
\text { (1960s-80s = age of protest) }\end{array}$ \\
\hline Improved security & $\begin{array}{l}\text { Improved security, reduced crime } \\
\text { opportunities }\end{array}$ \\
\hline
\end{tabular}

\section{Methods}

The five tests

The proposed tests are:

1. The preliminary evidence test

Are there reasonable empirical grounds to consider the hypothesis, even if it is disputed?

2. The cross-national test

Can the hypothesis be applied to different countries (e.g. to Canada for hypotheses developed for the US)?

3. The prior crime increase test

Is the hypothesis compatible, or at least not in contradiction, with the fact that crime was previously generally increasing for several decades?

4. The phone theft and e-crimes test Is the hypothesis compatible, or at least not in contradiction, with the fact that some crimes such as phone theft and e-crimes were increasing while many crime types were decreasing?

5. The varying trajectories test Is the hypothesis compatible, or at least not in contradiction, with variation in the timing and trajectory of crime falls both between countries and between crime types?
Each test is described in more detail below as it is applied to the hypotheses shown in Table 1.

\section{Results and discussion}

\section{The preliminary evidence test}

To pass this test, a hypothesis should not have been comprehensively falsified. The decision-making for this test uses the reviews by Levitt (2004) and Blumstein and Rosenfeld (2008) which are taken to be state-of-the-art works by leading scholars. For present purposes then, the hypotheses taken to have been falsified are increased capital punishment, newly implemented gun control laws, or laws allowing concealed weapons, and the strong economy, which were dismissed on the balance of evidence presented by Levitt (2004) as well as explicitly (or implicitly by exclusion) in the review of Blumstein and Rosenfeld (2008). Where either review determined that a hypothesis holds some empirical validity, then it passes the first test.

The civilizing process hypothesis is given a bye for this test as it is potentially credible despite the lack of evidence-based research. This is not without reservation, since as one of its proponents notes, it has problems

"not the least of which is whether such a theoretical perspective could be moved beyond the level of speculation and be subjected to more rigorous empirical tests." (Eisner 2008; 312)

All additional hypotheses are taken to pass the test for present purposes even though some are disputed and others claim only a minor role including demographics (generally found to account for around 10 to 15 percent - see Fox 2000) and immigration (Stowell et al. 2009 claim it accounts for 6 percent of the crime drop). Blumstein and Rosenfeld are critical of the notion that changing demographics induced the crime drop, observing that in the US,

"during the sharp crime drop of the 1990s, age composition changes were trending in the wrong direction: the number of 18-year-olds in the U.S. population was increasing while crime rates were declining for other reasons."

(Blumstein and Rosenfeld 2008; 20).

Nevertheless, for present purposes both demographics and immigration are taken to retain some support and pass the test. Likewise, while Levitt (2004), Blumstein and Rosenfeld (2008) and others have largely discarded the notion that changed policing strategies induced the crime drop, it is held to pass the present test because it continues to garner some support, particularly that of Zimring (2012) though that study does not seem to identify a clear mechanism by which policing caused 
crime to fall in New York. Hence generous criteria are used here for this test, with the components summarized in Table 2, and it serves primarily to separate the wheat from the chaff.

\section{The cross-national test}

Franklin Zimring's conversion to cross-national comparative research is worthy of recall:

"Closer inspection showed that the timing of the Canadian decline (1991-2000) fit perfectly with the timing of the declining in the United States (Zimring, 2006:Chapter 5). The extraordinary similarity of these trends in breadth, magnitude, and timing suggested that whatever was driving the decline in the United States was also operating in Canada. ... But ... Canada in the 1990s didn't increase its imprisonment, didn't hire more police per 100,000 population, and didn't have anything close to the economic boom we enjoyed south of the border." (Zimring 2006; 619)

Marc Ouimet had made similar observations (Ouimet 2002), while van Dijk et al. (2008) and Rosenfeld and Messner (2009) note many European countries with far less imprisonment than, but similar crime drops to, the US.

Hence others have already noted that some hypotheses fail what is here termed the cross-national test. It is a credit to the pioneering nature of US crime drop research and the dearth of studies elsewhere, that most such hypotheses are US-focused. In addition to those noted by Zimring it includes gun control laws, concealed weapons laws, the death penalty, more police officers,

Table 2 Preliminary evidence test

\begin{tabular}{|c|c|c|c|}
\hline Hypotheses & $\begin{array}{l}\text { Levitt } 2004 \\
\text { review }\end{array}$ & $\begin{array}{c}\text { Blumstein \& Rosenfeld } \\
2008 \text { review }\end{array}$ & $\begin{array}{l}\text { This } \\
\text { study }\end{array}$ \\
\hline Strong economy & $x$ & $x$ & $x$ \\
\hline Concealed weapons laws & $x$ & $x$ & $x$ \\
\hline Capital punishment & $x$ & $x$ & $x$ \\
\hline Gun control laws & $x$ & $x$ & $x$ \\
\hline Rising prison population & $\checkmark$ & $\checkmark$ & $\checkmark$ \\
\hline Policing strategies & $x$ & $x$ & $\checkmark$ \\
\hline More police & $\checkmark$ & $x$ & $\checkmark$ \\
\hline Legalization of abortion & $\checkmark$ & $x$ & $\checkmark$ \\
\hline Immigration & - & - & $\checkmark$ \\
\hline Consumer confidence & - & $\checkmark$ & $\checkmark$ \\
\hline Waning crack market & $\checkmark$ & $\checkmark$ & $\checkmark$ \\
\hline Childhood lead & - & $x$ & $\checkmark$ \\
\hline Changing demographics & $x$ & $x$ & $\checkmark$ \\
\hline Civilizing process & - & - & $\checkmark$ \\
\hline Improved security & - & - & $\checkmark$ \\
\hline
\end{tabular}

Legend: $\boldsymbol{\checkmark}=$ Pass. $\mathrm{x}=$ Fail. ' ${ }^{-}$' $=$not applicable. better policing strategies, the abortion hypothesis (see also Kahane et al. 2008 for a UK study finding no effect), and the waning crack market. The last three of these hypotheses had passed the first test, but since other countries did not have the same increase in police officers, the same change in abortion law, or similarly extensive crack markets, as the United States, they do not pass the second.

In relation to the immigration hypothesis, for present purposes it is assumed that other countries had similar patterns of immigration to the US. While this may prove an incorrect assumption it is conservative insofar as it allows the immigration hypothesis to pass the second test. Likewise, it is simplest for present purposes to assume other countries had similarly increasing consumer confidence (Rosenfeld 2009), due to the absence of contrary evidence for the present study. An aging population seems common across industrialised nations and so demographics is assumed to pass this test for present purposes. Pinker (2011) exposition of the civilizing process hypothesis is arguably applicable to most advanced countries, and taken to be so for present purposes.

The two hypotheses that pass this test more compellingly are the childhood lead hypothesis (for which Nevin (2007) presents cross-national data for several countries; see also Reyes 2012) and the security hypothesis relating to car theft that has been empirically tested in Australia, England and Wales, the Netherlands, and the United States (Farrell et al. 2011a, 2011b; Fujita and Maxfield 2012; van Ours and Vollaard 2013).

\section{The prior crime increase test}

Before the current spate of crime declines, it is fair to say that crime had increased rapidly over three decades or so in most advanced countries. A crime drop hypothesis need not necessarily explain why that is however, as it could be due to distinct factors, but it should not contradict the fact.

Although some of them already failed the preliminary evidence test, a key reason that gun control laws, the death penalty, concealed weapons laws, increased police numbers, and changed police strategies, were initially proposed is that they appeared to trigger change at about the right time (even those where the timing was subsequently found to be otherwise). The abortion hypothesis can also be assumed to pass this test as the timing of its effect is anticipated to coincide with the crime drop in the United States. Crack markets were also held to decline coincident with the fall in US crime. The civilizing process can be taken to pass this test because some explanation for prior crime increases is offered as due to the decline in the legitimacy of social institutions in the countercultures of the 'swinging sixties'. Tests of the 
security hypothesis find that the spread of more and better vehicle security coincides with major declines in vehicle crime, and so it is taken to pass this test.

This leaves five hypotheses that are taken to fail this test. The US economy and consumer confidence were strong prior to the $1990 \mathrm{~s}$, the prison population rose earlier, immigration was increasing prior to 1990, and demographic change has been more gradual. Levitt (2004) empirically examines whether his conclusions could apply to the period before the crime drop, finding that

"Between 1973 and 1991, the incarceration rate more than tripled, rising from 96 to 313 inmates per 100,000 residents. By my estimates, that should have reduced violent crime and homicide by over 30 percent and property crime by more than 20 percent. Note that this predicted impact of incarceration is much larger than for the latter period." (Levitt 2004; 184).

Levitt also finds that previous increases in police numbers should have reduced crime, as should the 1973 abortion legalization to some extent, with the crack market seemingly accounting for 16 percent of increased homicide and 8 percent of increased violence from 1973 to 1991. After some attempt to reconcile these findings it is argued that

"Thus, in contrast to the 1990s, the actual crime experience in the 1973-1991 period is not well explained by the set of factors analyzed in this paper... The real puzzle in my opinion, therefore, is not why crime fell in the 1990s, but why it did not start falling sooner." (Levitt 2004; 186)

However this is not the real puzzle, because it can never be that crime fell sooner. For the present author it highlights the fact that much of the analysis does not pass what is here termed the prior crime increase test.

This third test identifies an issue relating to the childhood lead hypothesis, which is that it is really a hypothesis for why pre-1990s crime increased. Increased lead poisoning caused the crime increase of the 1960s to 1990s. Following that, the removal of lead from gasoline and other sources is proposed to have induced a fall in crime, presumably to pre-lead levels. In essence, it argues, lead poisoning generated more motivated offenders. So, while this is not a criticism, it suggests it is a theory of crime, and only by its absence does lead poisoning provide a theory of the crime drop. It seems to be unique in that respect in seemingly claiming to explain all major trends and variation in crime over the last half century or so. This may be a line of enquiry that opens the lead hypothesis up to further investigation. It also implies that routine activity theory is not the compelling explanation for the pre-1990s crime increases that Cohen and Felson (1979) and others have so convincingly argued.

\section{The phone theft and E-crimes test}

Some crime types increased during the crime drop. Most notable is the large increases in internet-related crime. This likely occurred too late to have induced the crime drop as a switch from street crime, and also involves different resources, skills and rewards. Phone theft, in contrast, is a street crime which increased when others were decreasing (Mayhew and Harrington 2001), and at the time of writing in 2013 is experiencing a resurgence due to expensive smart phones. More generally, theft of valuable electronic goods such as laptops and GPS-Satnavs have increased. Any explanation of the decline in other crime types must not contradict these facts.

Most hypotheses fail this test because they suggest that all types of crime should have decreased. This is because their focus is the number or the motivation of offenders. The demographic hypothesis suggests the relative number of offenders decreased, which suggests commensurate declines in rates of all crime types should occur. Others with this trait are the childhood lead hypothesis, the abortion hypothesis, the immigration hypothesis (perhaps to a lesser extent depending on the identified mechanism of change), and the waning crack epidemic if it is held to reduce the number of motivated offenders. In fact, all of the hypotheses except one appear incompatible with increases in some types of crime. The exception is the security hypothesis which is flexible in allowing opportunity for some crimes to increase at the same time as that for others was decreasing.

\section{The varying trajectories test}

This test sounds similar to but differs significantly from the cross-national test. Whereas the cross-national test emphasised similarity between countries in the existence of a crime drop, this test reflects the sometimes considerable differences both between countries and between crime types within countries. Such differences can be in the timing (when does decline occur?) or trajectory (how fast is the decline?) for different crime types. Any theoretical explanation must be sufficiently flexible to account for the variation.

Some examples will clarify the justification for this test. The United States experienced major reductions in violence in the early 1990s but property crime (burglary and theft), according to the NCVS, had been declining since the early 1970s. The UK differs in experiencing more parallel dramatic drops in both violent and property crime. Australian property crime fell dramatically by 30-40 percent from 2001, and violent crime trends were 
mixed with a major decline in robberies alongside stable or increasing assaults (Mayhew 2012). New Zealand experienced falling property crime from the mid-1990s but violent crime was more stable or with slight increases (Mayhew 2012). When most crimes declines in a fashion similar to the US, car theft in Canada remained high through the 1990s then plummeted from the mid-2000s (Farrell and Brantingham 2013). Hence there are sometimes considerable differences between countries and within countries, and a hypothesis should not contradict those facts.

Most hypotheses fail this test because they suggest all types of crime should fall at the same time. For example, the childhood lead hypothesis fails to explain withincountry variation both in terms of how violent and property crime differ in some countries but not others (e.g. they fall similarly in the UK but not NZ or the US), and in terms of how some crimes fall at different times than others (e.g. Canadian car theft compared to other Canadian crimes). If the childhood lead hypothesis is said to apply only to violent crime then it does not explain property crime falls. If it is said to explain both violent and property crime then it cannot account for why one but not the other falls in some instances. The trajectory of car theft in Canada is a good example here, because car theft fell far later than most crimes, falling only from the mid-2000s onwards, which could not be due to a decline in lead poisoning.

The security hypothesis does not contradict this test. Specifically with respect to car theft, improved car security was introduced at different times in different countries. This timing can also differ from the spread of security for other crime types. Similarly, differences in the trajectory of the car theft decline between places, and between cities or regions within a country, are probably explained at least in part by differences in affluence and the rate of purchasing of new cars, and hence the speed of penetration of new and better security.

\section{Discussion}

The study findings are summarized in the matrix of Table 3. A hypothesis either fails or passes each test, with a fail shown as a cross (' $\mathrm{x}$ ') and a pass as a checkmark or tick (' $\checkmark$ ').

One hypothesis fails all five tests, four fail four, seven fail three, and two fail two tests (Table 3 ). The security hypothesis appears to pass each test. It suggests that more and better security drove the crime drop. Triangulation from various data signatures provided strong supporting evidence for car theft in Australia, and even stronger for the UK (Farrell et al. 2011a, 2011b), similarly strong evidence for the Netherlands (van ours and Vollaard 2013), and supporting evidence for the US
(Fujita and Maxfield 2012). Thus the security hypothesis passes the preliminary evidence and cross-national tests. The security hypothesis is crime specific. Car theft security improved and spread in the UK, for example, only shortly before phones became widely available to steal and the internet facilitated other crime types. Thus the hypothesis is compatible with the increases in phone theft and e-crimes, passing the third test. In the period before car security became more sophisticated and widespread, it was very easy to steal cars, and the number of car-related crime opportunities increased with car ownership (Wilkins 1967). Thus the security hypothesis is compatible with the existence of prior increases in crime, passing the fourth test. Car security was introduced and spread at different times in different countries, reflecting both market differences and purchasing rates for new cars, as well as differences in the timing of national legislation and other activities encouraging immobilizers. Thus the security hypothesis is compatible with variation in the timing and trajectory of the fall in car theft between countries, and variation between crime types within a country, and so passes the fifth test in relation to car crime. For example, Canada's decline in car theft occurred after it experienced declines in many crime types, but this is consistent with a later introduction of mandatory electronic immobilizers.

Thus viewed, the security hypothesis passes all tests in relation to car theft. Its main limitation is a lack of evidence relating to other crime types, though it is conceivable that different security measures impacted various types of crime at different times. It is also conceivable that, since many crimes are inter-linked, that a version of the keystone crime hypothesis (Farrell et al. 2008, 2011a) occurred in some instances. Car theft plays a key role in facilitating many other types of crime and so its removal, like that of the keystone in an archway, causes those around it to tumble. In addition, the security hypothesis does not contradict other empirical evidence relating to the nature of the declines in crime such as the fact that falls in repeat victimization and crime at hot spots play important roles (Weisburd et al. 2004, Thorpe 2007; Britton et al. 2012). The steeper declines in more concentrated crime that these studies found is consistent with crime falling more in places (such as New York City) where it was previously at a higher rate.

The security hypothesis proposes that more and better security plays a key role in driving down different types of crime, and that specifically:

"1. Security improvements, including specific security devices, vary for different crimes but have been widely implemented. 
Table 3 Summary of findings

\begin{tabular}{|c|c|c|c|c|c|}
\hline \multirow[b]{2}{*}{ Hypothesis } & \multicolumn{5}{|c|}{ Test } \\
\hline & $\begin{array}{c}\text { Preliminary } \\
\text { empirical }\end{array}$ & $\begin{array}{l}\text { Cross- } \\
\text { national }\end{array}$ & $\begin{array}{l}\text { Prior crime } \\
\text { increase }\end{array}$ & $\begin{array}{c}\text { E-crime \& } \\
\text { phone theft }\end{array}$ & $\begin{array}{c}\text { Variable } \\
\text { trajectories }\end{array}$ \\
\hline Strong economy & $x$ & $x$ & $x$ & $x$ & $x$ \\
\hline Concealed weapons laws & $x$ & $x$ & $\checkmark$ & $x$ & $x$ \\
\hline Capital punishment & $x$ & $x$ & $\checkmark$ & $x$ & $x$ \\
\hline Gun control laws & $x$ & $x$ & $\checkmark$ & $x$ & $x$ \\
\hline Rising prison population & $\checkmark$ & $x$ & $x$ & $x$ & $x$ \\
\hline Policing strategies & $\checkmark$ & $x$ & $\checkmark$ & $x$ & $x$ \\
\hline More police & $\checkmark$ & $x$ & $\checkmark$ & $x$ & $x$ \\
\hline Legalization of abortion & $\checkmark$ & $x$ & $\checkmark$ & $x$ & $x$ \\
\hline Immigration & $\checkmark$ & $\checkmark$ & $x$ & $x$ & $x$ \\
\hline Consumer confidence & $\checkmark$ & $\checkmark$ & $x$ & $x$ & $x$ \\
\hline Waning crack market & $\checkmark$ & $x$ & $\checkmark$ & $x$ & $x$ \\
\hline Childhood lead & $\checkmark$ & $\checkmark$ & $\checkmark$ & $x$ & $x$ \\
\hline Changing demographics & $\checkmark$ & $\checkmark$ & $x$ & $x$ & $x$ \\
\hline Civilizing process & $\checkmark$ & $\checkmark$ & $\checkmark$ & $x$ & $x$ \\
\hline Improved security & $\checkmark$ & $\checkmark$ & $\checkmark$ & $\checkmark$ & $\checkmark$ \\
\hline
\end{tabular}

Legend: $\boldsymbol{V}=$ Pass. $\mathrm{x}=$ Fail.

2. Different security measures work in different ways to reduce the crimes to which they are applied: they increase actual or perceived risk to the offender; and/ or they reduce actual or perceived reward for the offender; and/or they increase actual or perceived effort for the offender.

3. The different ways in which security measures work produce variations in expected changes in crime patterns associated with crime drops. These comprise expected security device crime change "signatures."

4. The specific falls in crime produced by improvements in security alongside their associated diffusions of benefit (preventive effects spilling out beyond the operational range of measures) to other targets and methods of committing crime are not matched by equivalent displacement." (Farrell et al. 2011a; 152).

With respect to other crime types, there is mounting evidence that burglary declines in different countries coincide with the spread of more and better household security (van Dijk 2008; Tilley et al. 2011). Clarke and Newman outline some more widespread security improvements that have occurred for various types of crime (Clarke and Newman 2006). Businesses in particular have become more aware of crime and the cost effectiveness of security, and business improvement districts are suggested to have brought down crime (MacDonald et al. 2010). Note that the security hypothesis can be viewed as a component of the broader framework of crime opportunity theory (see Clarke 2012). Changes in other crime opportunities may pass the tests outlined here, and warrant further research. For example, the declining value of some once-targeted goods may play a role in the decline in some aspects of acquisitive crime. Video cassette recorders then DVDplayers were drivers of burglary when they were valuable. It is also conceivable that shifts in urban form and traffic flows, including major changes such as growth in outof-city shopping malls in the 1990s, may have changed the movement patterns of potential targets and offenders in ways that reduced street crime. ${ }^{a}$ Tseloni et al. (2012) set out some steps towards a research agenda on crime opportunity theory including the security hypothesis.

\section{Conclusions}

This study offers five tests as a step in the direction of identifying a valid theory, or theories, of why many countries have experienced significant crime declines. An advantage of this approach is to allow some leeway in relation to instances where the direct evaluation evidence is disputed. Some of those disputes seem unlikely to be resolved in the near future and so the present study is useful in setting out additional assessment criteria. Thus, for example, whether Joyce's (2011) critique of the abortion legalization hypotheses is sustained need not be critical here because the hypothesis cannot explain non-US crime falls, and cannot be reconciled with either increasing phone theft and e-crime or with variable crime drop trajectories across crimes and places. 
The tests clarify particular aspects of some hypotheses. The demographics hypothesis retains an intuitive appeal for some commentators despite its impact being small at most, so its failure in other tests further clarifies its limitations. Demographic change suggests all types of crime would decline similarly in accordance with population change, with none increasing. Likewise, the childhood lead hypothesis offers no insight into why some types of crime increased when others were decreasing, why property crime fell alongside violence in the UK but had been falling for far longer than violence in the US, why there is significant variation in the crime drop between crime types in other countries, or why car theft in Canada fell only a decade or more after other crimes. And while the civilizing hypothesis is insightful when crime over the centuries is considered, its explanatory mechanism for dramatic recent crime drops seems weak and it lacks supporting evidence but, more importantly for present purposes, it also fails to explain why some crimes increased and why there is variation between crime types within countries.

Most hypotheses failed the phone theft and e-crime test as well as the variable trajectories test. Those hypotheses seem insufficiently nuanced to account for differences between crime types and places, particularly when crime increased or failed to decrease. This reflects their tendency to focus on the number or motivation of offenders. In contrast, the security hypothesis focuses on the number of suitable targets and capable guardians. Thus viewed, the routine activity theory provides a useful framework for comparing the hypotheses, even though it is not changes in legal routine activities that are considered as part of the security hypothesis.

The security hypothesis passes the five tests in relation to car theft. Repeated support from studies of car theft in Australia, England and Wales, the Netherlands, and the United States, suggest it might now be considered a theory rather than a hypothesis for that crime type. If so, on present evidence it also tends to eliminate rival hypotheses. This would suggest that while the fields of environmental criminology and crime science have been rather slow to address the crime drop, they offer a most promising perspective.

\section{Endnote}

${ }^{\mathrm{a}}$ I owe this last point to discussions with Pat and Paul Brantingham.

\section{Competing interests}

The author declares that he has no competing interest.

\section{Acknowledgements}

This paper was presented at the International Symposium on Environmental Criminology and Crime Analysis (ECCA) at Temple University, 17 June 2013. It draws on work conducted over the last several years in collaboration with Nick Tilley, Andromachi Tseloni and Jen Mailley, and more recently with
Louise Grove, Rebecca Thompson and Laura Garius, though they unfortunately cannot be blamed for mistakes herein. This includes research sponsored by the Economic and Social Research Council under grants RES000-22-2386 and ES/K003771/1. I am indebted to colleagues at ICURS for input and encouragement of various kinds, and to an ongoing collaboration with the Police Services Division of the Ministry of Justice of British Columbia and the Royal Canadian Mounted Police 'E-Division'. Thanks are also due to the students of my Spring 2013 graduate seminar at Simon Fraser University for a semester of enthralling discussions with only occasionally raised voices.

Received: 24 June 2013 Accepted: 2 August 2013

Published: 22 September 2013

\section{References}

Aebi, MF, \& Lande, A. (2012). Crime trends in western Europe according to official statistics from 1990 to 2007. In JJM van Dijk, A Tseloni, \& G Farrell (Eds.), The International Crime Drop: New Directions in Research (pp. 37-75). Basingstoke: Palgrave Macmillan.

Blumstein, A, \& Rosenfeld, R. (2008). Factors contributing to U.S. crime trends. In Understanding crime trends: Workshop report (National Research Council

Committee on Understanding Crime Trends, Committee on Law and Justice, Division of Behavioral and Social Sciences and Education, pp. 13-43). Washington, DC: National Academies Press.

Britton, A, Kershaw, C, Osborne, S, \& Smith, K. (2012). Underlying patterns within the England and Wales crime drop. In J van Dijk, A Tseloni, \& G Farrell (Eds.), The International Crime Drop: New Directions in Research (pp. 159-181). Basingstoke: Palgrave Macmillan.

Clarke, RV. (2012). 'Opportunity makes the thief. Really? So what?'. Crime Science, $1 ; 3,1-9$.

Clarke, RVG, \& Newman, G. (2006). Outsmarting the Terrorists. Westport, CT: Praeger.

Cohen, LE, \& Felson, M. (1979). Social Change and Crime Rate Trends: A Routine Activity Approach. American Sociological Review, 44, 588-608.

Eisner, M. (2008). Modernity strikes back? A historical perspective on the latest increase in interpersonal violence (1960-1990). International Journal of Conflict and Violence, 2(2), 289-316.

Farrell, G, \& Brantingham, PJ. (2013). 'The crime drop and the General Social Survey' Canadian Public Policy.

Farrell, G, Tilley, N, Tseloni, A, \& Mailley, J. (2008). The crime drop and the security hypothesis. British Society of Criminology Newsletter, 62, 17-21.

Farrell, G, Tilley, N, Tseloni, A, \& Mailley, J. (2011a). The crime drop and the security hypothesis. Journal of Research in Crime and Delinquency, 48(2), 147-175.

Farrell, G, Tseloni, A, \& Tilley, N. (2011b). The effectiveness of car security devices and their role in the crime drop. Criminology and Criminal Justice, 11(1), 21-35.

Fox, JA. (2000). Demographics and U.S. homicide. In A Blumstein \& J Wallman (Eds.), The crime drop in America (pp. 288-317). New York: Cambridge University Press.

Fujita, S, \& Maxfield, M. (2012). Security and the drop in car theft in the United States. In JJM van Dijk, A Tseloni, \& G Farrell (Eds.), The International Crime Drop: New Directions in Research (pp. 231-249). Basingstoke: Palgrave Macmillan.

Joyce, T. (2011). Abortion and crime: A review. In BL Benson \& PR Zimmerman (Eds.), Handbook on the Economics of Crime (pp. 452-487). Cheltenham: Edward Elgar.

Kahane, LH, Paton, D, \& Simmons, R. (2008). The abortion-crime link: Evidence from England and Wales. Economica, 75, 1-21.

Killias, M, \& Lanfranconi, B. (2012). The crime drop discourse - or the illusion of uniform continental trends: Switzerland as a contrasting case. In JJM van Dijk, A Tseloni, \& G Farrell (Eds.), The International Crime Drop: New Directions in Research (pp. 268-278). Basingstoke: Palgrave Macmillan.

Knepper, P. (2012). An international crime decline: Lessons for social welfare crime policy. Social Policy and Administration, 46(4), 359-376.

Levitt, S. (2004). Understanding why crime fell in the 1990s: Four factors that explain the decline and six that do not. Journal of Economic Perspectives, 18 163-190.

MacDonald, J, Golinelli, D, Stokes, RJ, \& Blumenthall, R. (2010). The effect of business improvement districts on the incidence of violent crimes. Injury Prevention, 16, 327-332. 
Mayhew, P. (2012). The case of Australia and New Zealand. In JJM van Dijk, A Tseloni, \& G Farrell (Eds.), The International Crime Drop: New Directions in Research (pp. 76-102). Basingstoke: Palgrave Macmillan.

Mayhew, P, \& Harrington, V. (2001). Mobile phone theft. London: Home Office. Nevin, R. (2007). Understanding international crime trends: The legacy of preschool lead exposure. Environmental Research, 104, 315-336.

Office of National Statistics. (2013). Crime in England and Wales, Year Ending March 2013. ONS Statistical Bulletin. London: Office of National Statistics.

Ouimet, M. (2002). Explaining the American and Canadian crime 'drop' in the 1990s. Canadian Journal of Criminology and Criminal Justice, 44(1), 33-50.

Pinker, S. (2011). Better Angels of Our Nature: Why Violence has Declined. New York: Viking.

Reyes, JW. (2012). Lead exposure and behavior: Effects on antisocial and risky behavior among children and adolescents (Working paper (draft February 2012)). Massachusetts: Amherst College.

Rosenfeld, R. (2009). Crime is the Problem: Homicide, Acquisitive Crime, and Economic Conditions. Journal of Quantitative Criminology, 25, 287-306.

Rosenfeld, R, \& Messner, SF. (2009). The crime drop in comparative perspective: the impact of the economy and imprisonment on American and European Burglary Rates. British Journal of Sociology, 60, 445-71.

Stowell, Jl, Messner, SF, McGeever, KF, \& Raffalovich, LE. (2009). Immigration and the recent violent crime drop in the United States: A pooled, cross-sectional time-series analysis of metropolitan areas. Criminology, 47(3), 889-929.

Thorpe, K. (2007). Multiple and repeat victimisation. In K Jansson (Ed.), Attitudes, perceptions and risks of crime: Supplementary Volume 1 to Crime in England and Wales 2006/07. Home Office Statistical Bulletn 19/07. London: Home Office.

Tilley, N, Tseloni, A, \& Farrell, G. (2011). Income disparities of burglary risk: Security availability and the crime drop. British Journal of Criminology, 51, 296-313.

Truman, JL, \& Planty, M. (2012). Criminal Victimization, 2011. Washington DC: U.S. Department of Justice, Office of Justice Programs, Bureau of Justice Statistics.

Tseloni, A, Mailley, J, Farrell, G, \& Tilley, N. (2010). Exploring the international decline in crime rates. European Journal of Criminology, 7(5), 375-394.

Tseloni, A, Farrell, G, Tilley, N, Grove, L, Thompson, R, \& Garius, L. (2012). Towards a comprehensive research agenda on opportunity theory and the crime falls. In JJM van Dijk, A Tseloni, \& G Farrell (Eds.), The International Crime Drop: New Directions in Research (pp. 286-299). Basingstoke: Palgrave Macmillan.

van Dijk, JJM. (2008). The World of Crime. London: Sage.

van Dijk, JJM, van Kesteren, JN, \& Smit, P. (2008). Criminal Victimisation in International Perspective: Key findings from the 2004-2005 ICVS and EU ICS. The Hague: Boom Legal Publishers.

van Dijk, JJM, Tseloni, A, \& Farrell, G (Eds.). (2012). The International Crime Drop: New Directions in Research. Basingstoke: Palgrave Macmillan.

van Ours, JC, \& Vollaard, B. (2013). The engine immobilizer: A non-starter for car thieves,' CESifo Working Paper: Public Choice, No. 4092 (Centre for Economic Studies and Ifo Institute). Munich: University of Munich.

Weisburd, D, Bushway, S, Lum, C, \& Yang, S-M. (2004). Trajectories of crime at places: A longitudinal study of street segments in the city of Seattle. Criminology, 42(2), 283-321.

Wilkins, LT. (1967). Social Policy, Action and Research: Studies in Social Deviance. London: Tavistock.

Zimring, FE. (2006). The value and necessity of transnational comparative study: Some preaching from a recent convert. Criminology, 5(4), 615-622.

Zimring, FE. (2012). The City that Became Safe: New York's Lessons for Urban Crime and its Control. London: Oxford University Press.

\section{Submit your manuscript to a SpringerOpen ${ }^{\circ}$ journal and benefit from:}

- Convenient online submission

$\rightarrow$ Rigorous peer review

- Immediate publication on acceptance

- Open access: articles freely available online

- High visibility within the field

- Retaining the copyright to your article

Submit your next manuscript at $>$ springeropen.com 